\title{
THE EFFECTIVENESS OF INTERNET AS A REFERENCE SOURCE IN TERMS OF STUDENTS LEARNING OUTCOMES AND MIND MAPPING
}

\author{
Wita Setianingsih, Mundilarto \\ Jurusan Pendidikan IPA FMIPA, Universitas Negeri Yogyakarta \\ wita@uny.ac.id, mundilarto@uny.ac.id
}

\begin{abstract}
This objective of the study is to find out the effectiveness of the Internet as a reference source for the classification of living things (1) in terms of students' learning outcomes, (2) which was reviewed from the students' mindmapping, (3) students' learning outcomes dan students' mindmapping. This was quasi-experimental study with the pretest-posttest control group design. The subject of this study was all of the grade VII students of SMP N 10 Yogyakarta. A sample of fifty-eight students grouped into two classes, namely class VII C and class VII $D$ was established using the purpose sampling technique. The instruments used were a test to find out the students' learning outcomes, observation sheets to reveal the students' ability in making a mind map, and the students' response questionnaire to reveal the students'opinion on the internet and mind map. The hypothesis test used was $T$ test and Hotelling 's $T^{2}$ multivariat test (manova). The results of the study shows that the internet as a reference source on the classification of living things on the grade VII students of SMP N 10 Yogyakarta is effective which was shown by the attainment of absolute gain score results for the treatment group. The score is 10, 14 higher than the control group, and the achievement of a gain standard score for the treatment group is 0.2 higher than the control group. The Internet has not been effective which was shown by the percentage result of the lower treatment class achievement compared with the control class's achievements in terms of the students' mindmapping. Both of them was shown F 8,118815 > P 3,16499
\end{abstract}

Key words: effectiveness, Internet, learning outcomes, mind map

\section{Pendahuluan}

Pendidikan merupakan salah satu unsur penting dalam kehidupan manusia. Pendidikan merupakan proses pendewasaan serta pembentukan pribadi. Pendidikan berlangsung sepanjang hayat. Pendidikan tidak hanya terjadi di dalam lingkungan sekolah, namun juga dalam lingkup keluarga maupun masyarakat. Pada pendidikan formal di sekolah, seseorang yang menempuh pendidikan akan menerima dasar-dasar pengetahuan formal sesuai dengan jenjang pendidikan yang ditempuh. Dasar - dasar pengetahuan tersebut menjadi pegangan dalam menjalani serta menghadapi tantangan dalam kehidupan.

Kota Yogyakarta identik dengan predikat Kota Pendidikan dan Kota Pelajar. Sesuai dengan predikat tersebut, berbagai lembaga pendidikan dapat dengan mudah dijumpai di Kota Yogyakarta. Berbagai lembaga pendidikan menawarkan keunggulan program pendidikan. Keunggulan yang ditawarkan pada umumnya adalah ketersediaan berbagai fasilitas dan sarana pendukung pembelajaran. Salah satu sarana pendukung yang ditawarkan adalah ketersediaan laboratorium komputer. Terutama laboratorium komputer yang telah dilengkapi dengan fasilitas jaringan untuk mengakses internet.

Semakin meratanya pengguna internet, memunculkan dua sisi mata uang yang tidak dapat dielakkan. Di satu sisi perkembangan tersebut menggembirakan, namun di sisi lain pergeseran orientasi penggunaan internet oleh pelajar memprihatinkan. Sebagai bagian dari teknologi informasi (TI), internet memang ibarat pisau bermata dua. Teknologi dapat bermanfaat apabila digunakan untuk melakukan hal-hal yang positif, seperti: mencari referensi bahan-bahan pelajaran sekolah, soal-soal latihan sesuai dengan mata pelajaran, diskusi dalam kaitan dengan mata pelajaran, mencari program beasiswa, konsultasi dengan pakar, maupun belajar jarak jauh. Seiring dengan kemudahan berbagai fasilitas yang ditawarkan penggunaan internet lebih bergeser kepada hal-hal yang negatif terutama yang berhubungan dengan jejaring sosial. Hal tersebut menjadi godaan, sehingga siswa dalam menggunakan internet cenderung bergeser untuk mencari hal lain diluar tujuan utamanya.

Keberadaan internet dalam dunia pendidikan dapat dimanfaatkan sebagai bagian dalam proses pembelajaran di sekolah. Menurut Teeler (2000,p.5), mengemukakan bahwa internet dalam perkembangannya telah digunakan sebagai basis aktivitas pembelajaran yang menyertai bahan belajar, seperti: mencari sumber informasi/referensi, mencari pengetahuan, mencari tugas, atau sekedar mencari hiburan dengan cara mensurvei materi yang telah tersedia pada internet. Internet kemudian berkembang sebagai sumber belajar dengan lingkungan belajar yang menyenangkan (edutainment). Internet memiliki 6 fungsi yaitu: (1) alat komunikasi, (2) akses informasi, (3) pendidikan dan pembelajaran, (4) Fungsi tambahan, (5) pelengkap, (6) Fungsi pengganti (Munir, 2008, p. 196-201).

Pembelajaran berbasis internet memiliki makna: (1) merupakan model penyampaian dan penyebarluasan isi yang fleksibel, (2) situasi dan presentasi sesuai konteks isi dan informasi, (3) pemenuhan akan sumber informasi yang memberi 
prespektif luas dan berbeda, (4) menyiapkan pembelajaran yang mengikat dan interaktif, (5) komunikatif dan mendukung pembelajaran mandiri, (6) tempat dan waktu belajar tidak terikat, (7) menciptakan kerjasama dan komunikasi. (Oliver, 2000, p. 157). Meskipun demikian beragamnya informasi yang dapat diperoleh melalui internet serta banyaknya link ke jaringan informasi lebih dari yang dibutuhkan sehingga sering menimbulkan masalah bagi siswa.

Melalui internet seseorang dapat mengetahui berita-berita teraktual dengan mengklik situs-situs di web. Sejalan dengan perkembangan informasi, pengetahuan dan pendidikan, internet dapat menyajikannya lebih cepat dari media konvensional. Selain menghemat tenaga, beragam materi di internet cenderung lebih up-to-date. Buku-buku teks umumnya memiliki rentang waktu antara proses penulisan, penerbitan, sampai ke tahap pemasaran. Apabila terdapat perbaikan maupun tambahan dari penulis buku, perubahan itu akan dimuat dalam edisi cetak ulang yang membutuhkan waktu. Dengan memanfaatkan internet kendala tersebut dapat teratasi, menggunakan search engine, materi-materi yang relevan dapat segera ditemukan, mengingat meng-upload sebuah halaman web tidak sesulit menerbitkan sebuah buku sehingga informasi yang disajikan relatif lebih aktual. Selain itu internet tidak mengenal batas geografis menjadikan internet sebagai salah satu sarana yang ideal untuk melakukan kegiatan belajar. Sebagai sumber yang menyajikan beragam informasi yang memiliki beberapa keunggulan dibandingkan media cetak dan terbukti banyak menunjang proses pembelajaran secara lebih efektif dan produktif, namun di sisi lain masih banyak kelemahan dan kekurangan. Di samping berbagai kemudahan tersebut maka tidak semua informasi yang didapat melalui sarana internet terjamin akurasinya.

Dalam menggunakan internet sifat dan karakteristik materi yang dipelajari menjadi pertimbangan. Sains merupakan salah satu materi yang menarik untuk dipelajari, beberapa topik materi terbantu pemahamannya dengan menggunakan internet. Hal ini karena dengan menggunakan internet dapat diperoleh gambaran secara visual yang lebih jelas mengenai suatu proses atau siklus yang tidak dapat secara langsung dilihat oleh indra dalam waktu yang singkat. Sains memiliki beragam pengertian Mattews (Martin, et, al, 2005, p. 11) mengemukakan bahwa: (1) science is human construct and human activity, (2) science is bound by history, (3)changes over time, (4) has teories that the under determination by empirical evidence, (5)has a knowledge base that is not absolute, (6)has methods and methodology that change over time, (7)deals in abstraction and ideas, (8) has research agendas that are influenced by social interest and technology, (9) in order to be learned, requires that children be attentive and intellectually enggaged. Sains didefinisikan sebagai (1) cara untuk berpikir, (2) cara untuk menyelidiki, (3) batang tubuh pengetahuan (Collete \& Chiapetta, 1994, p. 33-41). Sains juga memiliki karakteristik sebagai "characterised science as open-minded, universalist, disinterested and communal". (Frost \& Turner, 2005, p. 44). Dengan demikian maka perkembangan sains secepat perkembangan teknologi dan pemikiran manusia. Berbagai informasi, perkembangan penemuan sains terkini dapat lebih cepat diakses menggunakan internet daripada media cetak. Meskipun demikian tidak seluruh materi dalam pelajaran sesuai untuk dipelajari menggunakan internet.

Di samping kemudahan dan kecepatan akses beragam informasi sains menggunakan internet serta kesesuaian sifat dan karakteristik materi, tidak dapat dipungkiri bahwa keberadaan catatan siswa turut memberikan andil dalam keberhasilan belajar siswa. Belajar didefinisikan sebagai "learning is a process of active engagement with experience. It is what people do when they want to make sense of the world. It may involve the development or deepening of skills, knowlegde, understanding, awareness, values, ideas, and feelings or an increase in the capacity to reflect. Effective learning leads to change, development and the desire to learn more". (Braund \& Reiss, 2005, p.4). Dengan demikian catatan yang dibuat oleh siswa menggambarkan pemahaman siswa akan sesuatu yang sedang maupun telah dipelajari. Hal ini juga selaras dengan pembelajaran di Indonesia yang diarahkan agar siswa mampu mengembangkan long-term memory, life skill, dan memiliki kemampuan atau kompetensi untuk memahami konsep sains, serta tidak hanya menghafal konsep tersebut. Bahkan, saat ini diarahkan agar pembelajaran sains lebih terkonstruksi secara sosial (Sulistyowati \& Hamidah, 2008, p. 151).

Catatan yang mudah untuk di buka kembali lebih membantu siswa daripada catatan tebal dengan kalimat panjang. Selain menghemat waktu, juga menghemat tenaga maupun fikiran siswa. Hal ini terjadi karena siswa lebih fokus dan mudah mengingat serta memahami hubungan antar topik materi pada catatan yang berisi poin - poin penting. Untuk membantu siswa membuat mencatat atau ringkasan yang membantu siswa memahami suatu materi telah ada suatu teknik atau metode mencatat yang disebut sebagai mind map. Mind Map sering pula disebut sebagai mind mapping adalah metode mencatat untuk memudahkan siswa dalam mengingat materi pelajaran yang menggunakan manajemen otak untuk membuka seluruh potensi dan kapasitas otak yang masih tersembunyi (Buzan, 2007, p.10). Peta pikiran seperti otak manusia yang memiliki banyak cabang. Pembuatan peta pikiran membebaskan penulisnya membuat banyak cabang dan mengkaitkan antar cabangnya. Terdapat 6 langkah dalam membuat peta pikiran, yaitu: (1) menuliskan tema atau topik sentral ditengah kertas, (2) menggunakan gambar atau foto, (3) menggunakan lebih dari satu macam warna, (4) membuat hubungan antar cabang, (5) menggunakan garis lengkung, dan (6) menggunakan kata kunci. (Buzan, 2005, p.11).

Apabila dihubungkan dengan teori pendidikan terdapat kesesuaian antara mind map dengan teori 
pendidikan yang telah ada. Salah satunya adalah kesesuaian Teori Piaget (Konstruktivisme) dengan mapping (mind map) yaitu teori konstruktivisme Piaget dan mind map memiliki kesesuaian sebagai berikut: (a) Siswa dapat menuangkan ide berdasarkan pengalaman yang telah diperoleh sebelumnya sesuai kreativitasnya masing-masing. (b) Mapping memberikan ruang kognitif yang besar melalui analisis yang dibuat, (c) Siswa mendapat kesempatan mengemukakan gagasan atau ide dengan bahasanya sendiri, (d) Siswa memperoleh kesempatan untuk menuangkan pengalamannya sehingga menjadi kreatif dan imajinatif, (e) Mendorong siswa untuk lentur terhadap perubahan gagasan. Melalui mapping pengetahuan dan pengalaman belajar dapat dijembatani dari yang abstrak ke konkrit. (Swadarma , 2013, p. 26).

Berdasarkan observasi awal diperoleh informasi bahwa mata pelajaran sains khususnya biologi merupakan salah satu mata pelajaran yang menjadi momok siswa karena banyaknya hafalan dan nama latin. Hal ini menyebabkan hasil belajar siswa dalam sains terutama biologi belum optimal meskipun pada saat pembelajaran berlangsung siswa terlihat antusias dan bersemangat namun pada hasil akhirnya belum menggembirakan.

Sumber referensi yang biasanya digunakan di sekolah adalah buku pegangan siswa maupun bukubuku yang ada di perpustakaan. Buku yang telah ada tersebut meskipun isinya baik namun menurut siswa kurang menarik. Catatan yang dimiliki oleh siswa cenderung berupa catatan dengan kalimat panjang bahkan ada siswa yang tidak memiliki catatan dan mengandalkan buku teks maupun LKS. Hal ini menyebabkan siswa mengalami kesulitan pada saat belajar kembali.

Di sisi lain kemampuan yang miliki siswa dalam menggunakan internet hampir merata meskipun tidak semua siswa memiliki fasilitas untuk dapat mengakses internet secara pribadi dirumah. Ketersediaan fasilitas internet di sekolah dapat menjadi salah satu faktor pendukung untuk menggiatkan dan memotivasi siswa dalam belajar sains khususnya materi biologi. Informasi yang disajikan di internet lebih menarik dengan bantuan gambar dan warna.

Berdasarkan hal tersebut maka perlu diteliti mengenai keefektifan dari penggunaan internet sebagai sumber referensi terhadap materi klasifikasi makhluk hidup ditinjau dari hasil belajar dan mind map siswa.

\section{Metode Penelitian}

Jenis Penelitian

Penelitian menggunakan metode quasi eksperimen pretest - posttest control goup design yang bertujuan untuk membandingkan dua perlakuan yang berbeda kepada subjek penelitian. Penelitian ini dilakukan untuk mengetahui keefektifan penggunaan internet sebagai sumber referensi ditinjau dari hasil belajar dan ketercapaian mind map siswa.

Populasi dan Sampel Penelitian

Populasi yang dipergunakan dalam penelitian ini adalah semua siswa kelas VII SMP N 10 Yogyakarta tahun ajaran 2009/2010 sebanyak 144 orang siswa. Sampel penelitian sitentukan dengan purposive sampling dengan banyak sampel 58 orang siswa yang terbagi dalam 2 kelas, 29 orang sebagai kelas perlakuan dan 29 orang sebagai kelas kontrol.

Prosedur

Prosedur penelitian quasi eksperimen terdiri dari tiga tahap, yaitu tahap persiapan, tahap penelitian, dan tahap penyelesaian.

Pertama, tahap persiapan meliputi pengajuan judul tesis, pembuatan proposal tesis, permohonan ijin survei, persiapan instrumen penelitian dan konsultasi instrumen penelitian.

Kedua, tahap penelitian meliputi seluruh kegiatan yang berlangsung di lapangan, yaitu uji coba instrumen dan pengambilan data.

Ketiga, tahap penyelesaian meliputi analisis data dan penyusunan laporan.

Data, Intrumen, dan Teknik Pengumpulan Data

Instrumen pengumpulan data menggunakan tes hasil belajar, lembar observasi dan angket. Tes hasil belajar digunakan untuk mengukur tingkat penguasaan materi. Lembar observasi digunakan untuk mengungkap kemampuan siswa dalam membuat mind map. Angket digunakan untuk menjaring respon siswa terhadap pembelajaran.

Teknik Analisis Data

Analisis data yang dilakukan untuk ketercapaian hasil belajar dilakukan dengan membandingkan skor rata-rata dari dua pembelajaran untuk mengetahui keefektifan hasil belajar.

Penghitungan peningkatan hasil belajar dilakukan dengan teknik Gain Standar (David E. Meltzer, 2002, p. 1260), dengan rumus:

$$
\text { Gain standard }=\frac{\text { Score postest }- \text { score pretest }}{\text { Score maximum }- \text { score pretest }}
$$

Kriteria hasil gain standartd yang digunakan adalah sebagai berikut $\leq 0,3=$ rendah, $0,3 \leq \mathrm{x} \leq 0,7=$ sedang dan $\geq 0,7=$ tinggi. Selain itu juga digunakan absolute gain dengan rumus sebagai berikut:

absolute gain $=$ score posttest - score pretest .

Analisis data untuk ketercapaian pembuatan mind map dilakukan dengan menggunakan rumus presentase keberhasilan sebagai berikut:

$$
\mathrm{N}_{\mathrm{K}}=\left(\frac{\mathrm{N}_{\mathrm{A}}}{\mathrm{N}_{\mathrm{T}}}\right) \times 100 \%
$$


Dengan $\mathrm{N}_{\mathrm{k}}=$ ketercapaian siswa, $\mathrm{N}_{\mathrm{A}}=$ nilai faktual yang dicapai setiap siswa dan $\mathrm{N}_{\mathrm{T}}=$ nilai maksimal ideal yang dapat dicapai siswa.

Data respon siswa dianalisis dengan menghitung persentase hasil penskoran jawaban siswa menggunakan rumus

$$
\mathrm{S}=\frac{\mathrm{R}}{\mathrm{N}} \mathrm{x} 100 \% \text { (Purwanto, 2010,p. 112) }
$$

Dengan $\mathrm{S}=$ nilai yang dicari, $\mathrm{R}=$ jumlah skor yang diperoleh dan $\mathrm{N}=$ nilai skor maksimum.

Berdasarkan variabel-variabel yang diuji yaitu variabel bebas (jenis sumber referensi) dan variabel terikat (hasil belajar dan ketercapaian pembuatan mind map) maka uji hipotesis yang digunakan adalah uji t dan Uji Hotelling`s $\mathrm{T}^{2}$ analisis varian multivariate (MANOVA) (Stevens, 2009, p. 145-171).

Hasil belajar dan ketercapaian pembuatan mind map siswa dalam pembelajaran menggunakan sumber referensi internet dan tidak menggunakan internet diselidiki melalui tahapan-tahapan sebagai berikut.

Pertama, uji korelasi yang dilakukan berdasarkan skor posttest. Perhitungan nilai korelasi menggunakan analisis korelasi Product Moment Pearson. Sampel dinyatakan berkorelasi jika harga $r$ hasil perhitungan lebih besar daripada harga $r$ tabel pada $\mathrm{n}$ sampel, dan sebaliknya jika harga $\mathrm{r}$ hasil perhitungan lebih kecil dari harga $r$ tabel pada $n$ sampel maka sampel bersifat independen.

Kedua, Uji normalitas yang digunakan adalah uji Chi Kuadrat $\left(\chi^{2}\right)$. Data dikatakan berdistribusi normal pada taraf signifikansi 5\% apabila harga $\chi^{2}$ hitung $\leq \chi^{2}$ tabel dengan derajat bebas $\mathrm{n}-1$, atau apabila harga probabilitas perhitungan $\geq 0,05$.

Ketiga, Uji homogenitas. Sampel penelitian dikatakan dari populasi yang homogen pada taraf signifikansi $5 \%$ apabila harga probabilitas perhitungan lebih besar daripada 0,05 .

Keempat, yaitu uji hipotesis. Apabila data yang diperoleh homogen, berdistribusi normal dan bersifat independent, maka digunakan teknik analisis independent sample t-test. Uji hipotesis yang dilakukan dalam penelitian ini dengan dua cara yaitu uji $t$ dan menggunakan uji multivariat. Uji $t$ dilakukan untuk mengetahui keefektifan setiap variabel terhadap sumber referensi internet, sedangkan uji multivariat Hotelling`s $\mathrm{T}^{2}$ dilakukan ntuk mengetahui keefektifan hasil belajar dan mind map apabila dilakukan secara bersama-sama. Kriteria pengujian hipotesis adalah $\mathrm{H}_{0}$ ditolak pada taraf signifikansi 5\% jika nilai probabilitas lebih kecil dari 0,05 .

\section{Hasil Penelitian dan Pembahasan}

Data dalam penelitian ini meliputi data skor pretest dan post test untuk hasil belajar kognitif, data skor penelusuran referensi dan pembuatan mind map untuk ketercapaian pembuatan mind map untuk ranah afektif serta data skor jawaban siswa untuk angket respon siswa terhadap pembelajaran. Berdasarkan data yang diperoleh kemudian dilakukan analisis untuk memperoleh makna skor tersebut terhadap penelitian. Sebelum dilakukan perhitungan lanjut dilakukan perhitungan prasyarat terlebih dahulu. Perhitungan prasyarat yang dilakukan adalah (1) perhitungan korelasi untuk mengetahui apakah data yang diperoleh berasal dari suatu sampel yang bersifat independen atau tidak. Pada perhitungan korelasi diperoleh hasil bahwa data yang digunakan dalam penelitian mempunyai harga korelasi $\mathrm{r}_{\text {hasilbelajar }} 0,371<\mathrm{r}_{\text {tabel }} 0,430$ dan $\mathrm{r}_{\text {mindmap }}$ $0,353<\mathrm{r}_{\text {tabel }} 0,430$ dengan demikian maka nilai $\mathrm{r}_{\text {hitung }}$ untuk hasil belajar maupun mind map $<\mathrm{r}_{\text {tabel }}$ sehingga data bersifat independen. (2) perhitungan normalitas. Data dalam penelitian ini terdistribusi normal dengan $\chi_{\text {hit hasil belajar }}^{2} 18,552<\chi_{\text {tab }}^{2} 19,675 ; \chi_{\text {hit gain abs }}^{2} 26,414<$ $\chi_{\text {tab }}^{2} 27,587 ; \chi_{\text {hit gain standar }}^{2} 19,379<\chi_{\text {tab }}^{2} 46,19$ dan $\chi_{\text {hit }}^{2}$ mind map $10,552<\chi_{\text {tab }}^{2} 12,592$. Nilai $\chi_{\text {hit }}^{2}<\chi_{\text {tab }}^{2}$ dengan derajat bebas $n-1$, sehingga semua data berdistribusi normal. (3) perhitungan homogenitas. Pada uji homogenitas diperoleh harga probabilitas (sig) > 0,05. Dengan harga probabilitas $>0,05$ maka dapat dikatakan bahwa sampel berasal dari sampel yang homogen. Dengan demikian data dalam penelitian ini memiliki sifat independen, terdistribusi normal dan homogen.

Data yang telah diperoleh dan telah dilakukan uji prasyarat terbagi menjadi dua bagian utama data. Data pertama adalah data hasil belajar siswa. Berdasarkan data skor pretest yang digunakan sebagai acuan awal kemampuan awal siswa sebelum mendapatkan perlakuan dan data skor posttest yang digunakan sebagai hasil belajar akhir setelah siswa mendapatkan perlakuan, diperoleh data peningkatan yang dinyatakan dengan nilai Gain Absolute dan Gain Standard.

Tabel 1. Rata-Rata Peningkatan Skor Hasil Belajar Kognitif Siswa

\begin{tabular}{cccccc}
\hline \multirow{2}{*}{ Kelas } & \multicolumn{2}{c}{ Nilai rerata } & \multicolumn{3}{c}{ Gain } \\
& Pretest & Posttest & Absolut & Standar & Kriteria \\
\hline $\mathrm{K}$ & 47,79 & 74,21 & 26,41 & 0,47 & Sedang \\
$\mathrm{P}$ & 45,38 & 81,93 & 36,55 & 0,67 & Sedang
\end{tabular}

Sumber: hasil olah data primer

Berdasarkan tabel 1 baik kelas P maupun kelas $\mathrm{K}$ mengalami kenaikan rerata nilai dari nilai pretest dan posttest. Kelas $\mathrm{P}$ adalah kelas perlakuan yang menggunakan internet sebagai sumber referensi materi sains (klasifikasi) dan kelas K adalah kelas kontrol yang tidak menggunakan internet dalam mencari referensi. Nilai pretest yang diperoleh kelas $\mathrm{K}$ lebih tinggi dibandingkan nilai pretest kelas $\mathrm{P}$, namun pada nilai posttest nilai yang diperoleh kelas $\mathrm{P}$ lebih tinggi daripada kelas K. Berdasarkan hal tersebut maka kelas $\mathrm{P}$ memperoleh hasil yang lebih baik dalam hal hasil belajar ranah kognitif dibandingkan kelas $\mathrm{K}$. Berdasarkan nilai perhitungan gain absolut kelas $\mathrm{P}$ lebih tinggi 10,14 dari pada kelas $\mathrm{K}$ dan pada perhitungan gain standar diperoleh hasil kelas $\mathrm{P}$ lebih tinggi sebesar 0,2 dari kelas K. Meskipun demikian 
besarnya kenaikan yang dinyatakan dalam gain untuk kedua kelas tersebut masih termasuk dalam kategori sedang.

Data kedua adalah data skor ketercapaian pembuatan mind map. Pada data ini diperoleh dua data yaitu data aspek pencarian referensi dan data pembuatan mind map. Data yang diperoleh kemudian diolah sehingga diperoleh persentase yang menunjukkan keberhasilan ketercapaian pembuatan mind map. Rangkuman perolehan hasil pada ketercapaian pembuatan mind map tersaji dalam tabel 2 . Tabel 2. Ketercapaian Pembuatan Mind Map Siswa (\%)

Sumber: hasil olah data primer

Berdasarkan tabel 2 diketahui bahwa rerata total ketercapaian pembuatan mind map adalah $94,3 \%$ untuk kelas K dan 89,3\% untuk kelas P. Apabila dirunut pada aspek pencarian referensi dan pembuatan mind map, diperoleh hasil pada pencarian referensi kelas $\mathrm{K}$ memperoleh persentase lebih tinggi daripada kelas $\mathrm{P}$, demikian pula pada pembuatan mind map. Dengan demikian maka pada ketercapaian pembuatan mind map kelas $\mathrm{K}$ memperoleh hasil lebih besar dari kelas $\mathrm{P}$ untuk kedua aspek.

Hal ini dapat terjadi karena rata-rata awal kemampuan siswa untuk melakukan pencarian referensi dan pembuatan mind map pada kedua kelas tidak dapat benar-benar dibuat sama. Pada aspek pencarian referensi kelas $\mathrm{K}$ menggunakan buku sebagai sumber referensi sehingga siswa telah lebih familier dan mudah untuk membuka kembali apabila diperlukan. Pada kelas $\mathrm{P}$ sumber referensi yang digunakan adalah internet, meskipun siswa telah memiliki kemampuan yang memadai untuk menggunakan internet namun ternyata siswa hasil yang diperoleh siswa tidak seperti yang diperkirakan. Hal ini dapat terjadi sebab pada saat siswa melakukan pencarian referensi menggunakan internet siswa tidak sekedar mampu mengoperasikan internet namun siswa juga perlu untuk dapat mengingat dan memperoleh poin penting dalam setiap pencarian. Untuk membuat mind map diperlukan suatu keterampilan, dan keterampilan tersebut tidak dapat diperoleh secara instan, siswa yang belum terbiasa mencatat poin penting dan memetakan hubungan antar poin mengalami kesulitan untuk menuliskan dalam bentuk mind map demikian pula untuk melihat kembali ke sumber referensi menggunakan internet. Hal ini dapat menjelaskan mengapa hasil pada kelas kontrol yang menggunakan buku sebagai sumber referensi lebih tinggi daripada kelas perlakuan yang menggunakan internet sebagai sumber referensi.

Hasil rerata skor pengamatan untuk aspek pencarian referensi dapat disajikan dalam gambar 1 sebagai berikut:

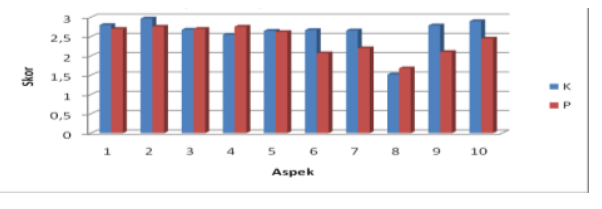

Gambar 1. Histogram rerata skor ketercapaian aspek pencarian referensi

Aspek pencarian referensi meliputi (1) Perhatian, (2) Kegigihan pencarian informasi, (3) Ketelitian mencatat hal penting, (4) Ketaatan menggunakan kata kunci, (5) Ketekunan membaca informasi, (6) keberanian bertanya, (7) kepatuhan pada tugas, (8) kedisiplinan, (9) keseriusan dalam tugas dan

\begin{tabular}{ccccccccr}
\hline \multirow{2}{*}{ Kelas } & $\begin{array}{c}\text { Pencarian } \\
\text { referensi }\end{array}$ & \multicolumn{9}{c}{ Pembuatan Mind Map ke- } & Rerata & keju \\
\hline K & 87,3 & 94,3 & 94,9 & 95,5 & 99,6 & 94,3 & jura \\
P & 80 & 93,1 & 90,7 & 90,4 & 92,2 & 89,3 & n. \\
& & & & & & & Ber \\
dasa
\end{tabular}

rkan histogram tersebut aspek no 8 yaitu kedisiplinan memiliki persentase paling rendah dibandingkan ke 9 aspek lainnya untuk kedua kelas. Dengan demikian perlu adanya perhatian untuk meningkatkan kedisiplinan siswa dalam mengerjakan.

Pembuatan Mind Map setiap aspek disajikan dalam gambar 2.

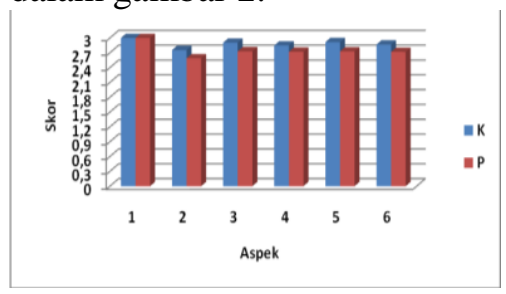

Gambar 2. Histogram rerata skor ketercapaian pembuatan mind map

Aspek dalam pembuatan mind map meliputi: (1) Kepatuhan penulisan tema di tengah bagian kertas, (2) Kedisiplinan menghubungkan tema tidak dengan garis lurus, (3) Menggunakan gambar sebagai pengingat, (4) Penggunaan lebih dari satu warna, (5) Kerjasama dan diskusi, (6) Ketelitian peletakkan kata kunci di tiap tema. Pada pembuatan mind map kedua kelas mempunyai persentase yang rendah pada aspek no 2 yaitu kedisiplinan untuk tidak menggunakan garis lurus sebagai garis penghubung antar tema. Untuk dapat melakukan hal tersebut perlu suatu pembiasaan tidak cukup hanya dengan pemahaman karena pada saat penuangan pikiran dalam bentuk mind map pikiran telah secara otomatis melakukannya.

Hasil penuangan atau pembuatan mind map oleh siswa disajikan dalam gambar 3.

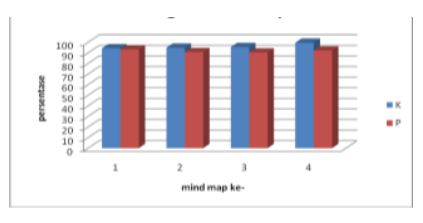

Gambar 3. Histogram persentase penuangan mind map

Penuangan mind map diukur sebanyak empat kali dengan harapan semakin sering berlatih membuat mind map hasil yang diperoleh akan semakin baik. Namun dalam gambar 3 terlihat bahwa kelas $\mathrm{K}$ memperoleh hasil persentase lebih tinggi dari kelas $\mathrm{P}$ 
dalam penelitian ini hal tersebut dapat terjadi berhubungan dengan jenis sumber referensi yang digunakan untuk pencarian referensi.

Setelah seluruh uji prasyarat dilakuakn dan terpenuhi maka data yang diperoleh kemudian dilakukan uji lanjut dengan uji hipotesis. Berdasarkan perhitungan uji hipotesis untuk hasil belajar pada absolute gain diperoleh nilai $t_{\text {hitung }} 2,640>t_{\text {tabel }} 1,673$ maka $H_{0}$ ditolak.

Dari taraf signifikansi hitung yaitu 0,0055 yang nilainya lebih kecil daripada 0,05 , juga dapat disimpulkan bahwa $H_{0}$ ditolak. Berarti ketercapaian skor hasil belajar dilihat dari absolute gain untuk kelas yang menggunakan internet lebih tinggi dari skor kelas yang tidak menggunakan internet.

Berdasarkan hasil uji hipotesis untuk hasil belajar berdasarkan standart gain diperoleh nilai $t_{\text {hitung }}$ $2,215>t_{\text {tabel }} 0.05, \quad 1,673$ maka $H_{0}$ ditolak. Dari taraf signifikansi hitung yaitu 0,0155 yang nilainya lebih kecil daripada 0,05 , juga dapat disimpulkan bahwa $H_{0}$ ditolak. Berarti ketercapaian skor hasil belajar dilihat dari standart gain untuk kelas yang menggunakan internet lebih tinggi dari skor kelas yang tidak menggunakan internet.

Berdasarkan uji hipotesis yang telah dilakukan, tampak bahwa ada ketercapaian skor yang lebih tinggi pada hasil belajar ranah kognitif siswa dengan menggunakan internet sebagai sumber referensi dibandingkan hasil belajar siswa dengan pembelajaran biasa menggunakan pencarian referensi textbook (tidak menggunakan internet).

Uji hipotesis pada ketercapaian pembuatan mind map diperoleh hasil harga $t$ adalah - 2,626 dengan tingkat signfikansi 0,011. Berdasarkan tabel, nilai $t$ untuk $d f=56$ adalah 1,673. Karena nilai $t_{\text {hitung }}<t_{\text {tabel }}$ 0.05 , maka $H_{0}$ diterima. Dari taraf signifikansi hitung yaitu 0,011 yang nilainya lebih kecil daripada 0,05 , juga dapat disimpulkan bahwa $H_{0}$ diterima. Berarti ketercapaian skor afektif ketercapaian pembuatan mind map untuk kelas yang menggunakan internet lebih rendah dari skor kelas yang tidak menggunakan internet.

Pada uji Manova diperoleh hasil F 8,118815> P 3,16499, sehingga dapat disimpulkan bahwa terdapat perbedaan keefektifan jenis sumber referensi terhadap hasil belajar dan ketercapaian pembuatan mind map secara bersama-sama. Internet sebagai sumber referensi efektif apabila ditinjau dari hasil belajar dan mind map secara bersama-sama.

\section{Simpulan dan Saran}

Simpulan

Berdasarkan hasil analisis data dan pembahasan, dapat ditarik kesimpulan sebagai berikut. Pertama, Internet efektif digunakan sebagai sumber referensi materi sains (klasifikasi) di SMP N 10 Yogyakarta ditinjau dari hasil belajar siswa. Kedua, Internet belum efektif digunakan sebagai sumber referensi materi sains (klasifikasi) di SMP N 10 Yogyakarta dilihat dari catatan mind map siswa. Ketiga, terdapat Internet efektif sebagai sumber referensi materi sains (klasifikasi) ditinjau dari hasil belajar dan ketercapaian pembuatan mind map secara bersamasama..

\section{Saran}

Berdasarkan hasil penelitian dan pembahasan serta mengingat keterlaksanaan penelitian, saran yang dapat disampaikan sebagai berikut. Pertama, bagi peneliti selanjutnya dapat dilakukan penelitian lanjut dengan mempertimbangkan variabel pengukuran IQ maupun penelusuran data motivasi. Kedua, bagi peneliti selanjutnya dapat dilakukan penelitian penerapan pembelajaran IPA menggunakan internet serta melibatkan metode pencatatan Mind Mapping (peta pikiran) dengan memperhatikan kesesuaian karakteristik dan sifat materi. Ketiga, Bagi peneliti selanjutnya dapat dilakukan penelitian lebih lanjut untuk penugasan dengan menggunakan internet dengan pengukuran ketercapaian sikap ilmiah serta penuangan laporan dalam bentuk mind mapping untuk materi lain dengan mempertimbangkan kesesuaikan karakteristik dan sifat materi. Keempat, bagi guru untuk meningkatkan wawasan, kreativitas dan keberanian mencoba untuk memanfaatkan berbagai sumber referensi serta memperkenalkan teknik mencatat sehingga dapat membantu siswa mengoptimalkan kemampuannya dan pada akhirnya dapat meningkatkan hasil belajar.

\section{Daftar Pustaka}

Braund, M \& Reiss, M. (2005). Learning science outside the classroom.NewYork: Taylor \& Francis e-Library

Buzan, T. (2005). How to mind map: mind map untuk meningkatkan kreativitas. Jakarta: PT Gramedia Pustaka Utama

Buzan, T. (2007). Buku pintar mind map untuk anak. Jakarta: PT. Gramedia Pustaka Utama

Collete, A.T. \& Chiapetta, E.L. (1994). Science instruction in the middle and secondary school.3rd Ed. New York: Macmillan Publishing Company.

Frost, J. \& Turner, T (2005). Learning to teach english in secondary school. New York: Taylor \& Francis e-library

Joyce, W. (2005). Menjadi super kreatif melalui metode pemetaan pikiran. Bandung: PT. Mizan Pustaka

Martin, R.S, C. Franklin T \& Gerlovich, J (2005). Teaching science for all children: inquiry methods for constructing understanding. Boston: Pearson Education Inc.

Meltzer, D.E. (2002). The relationship beetwen mathemathic preparation and conceptual learning gain in physics: a possible "hidden variable" in diagnostic pretest scores [Versi 
electronik]. American Journal Physics 70,12, 1259-1267

Munir. (2008). Kurikulum berbasis teknologi informasi dan komunikasi. Bandung: Alfabeta

Oliver, R. (2000). Using the New Technologies to create learning partnership. (eds). Changing university teaching, refection on creating educational technologies. London: Kogan Page Limited

Purwanto, N. (2006). Psikologi pendidikan. Bandung: PT Remaja Rosdakarya

Stevens, JP. (2009). Applied Multivariate Statistics for The Social Science $5^{\text {th }}$ edition. New York: Routledge Taylor \& Francis Group.

Sulistyowati, E \& Hamidah, N. (2008). Science as Socially-Constructed Knowledge. Proceeding of The First Seminar International on Matematics and Science Education. Faculty of Tarbiyah and Teacher's Training, Islamic State University Syarif Hidayatullah Jakarta, October 28th-29th, 2008, hal 150 - 160.

Swadarma, D. (2013). Mind mapping dalam kurikulum pembelajaran.Jakarta: PT Elex Media Komputindo Kompas Gramedia

Teeler, D. (2000). Use the internet ELT. England: Pearson Education Limited

\section{Profil Singkat}

Wita Setianingsih dilahirkan di kota Yogyakarta pada tanggal 22 April 1980. Penulis meraih gelar sarjana (S1) di Program Studi Pendidikan Biologi FMIPA UNY pada tahun 2002. Saat ini sedang menjalani penyusunan tesis pada Program Studi Pendidikan Sains Program Pascasarjana, Universitas Negeri Yogyakarta.

Prof. Dr. Mundilarto, M.Pd, dilahirkan di kota Bantul pada tanggal 24 Maret 1952. Penulis meraih gelar sarjana (S1) di IKIP Yogyakarta pada tahun 1981, gelar magister (S2) di IKIP Jakarta pada tahun 1987, gelar doktoral (S3) di Universitas Pendidikan Indonesia Bandung pada tahun 2001, dan dikukuhkan sebagai guru besar bidang ilmu penelitian pendidikan fisika Universitas Negeri Yogyakarta di Yogyakarta pada bulan September tahun 2005. Sekarang penulis aktif mengajar sebagai dosen di Universitas Negeri Yogyakarta. 